\title{
POLITIKK
}

\section{Makrellkonflikten og strategisk klimafornekting}

\author{
Olav Anders Totland \\ Fridtjof Nansen Institutt
}

\begin{abstract}
Sammendrag
Kor godt rusta er internasjonale ressursforvaltingsregime til å tilpasse seg klimaendringar? Klarar slike regime å inkludere nykommarar på ein konstruktiv måte, eller vinn realpolitiske vurderingar fram og ein hegnar om eigne ressursar? Denne artikkelen vil utforske dette og sjå på korleis klimaforsking blir brukt politisk til å legitimere krav på ressursar. Til dette blir makrellkonflikten i Nordaust-Atlanteren frå 2008-2014 undersøkt. Etter at makrellen endra vandringsmønster lenger nord og vest, vart det konflikt mellom Noreg og EU på eine sida og Island og Færøyane på andre sida. Folkeretten gjev eit stort rom for å tolke denne tvisten ulikt hjå partane. Dette spelerommet, kombinert med ein låg grad av tilpassing til nykommarstatar, førte til at det etablerte forvaltingsregimet braut saman. I løpet av konflikten vart det tydeleg at partane hadde svært ulike forklaringar på endringa i makrellens vandringsmønster. Klima- og miljøforsking vart trekt i tvil og brukt strategisk av aktørane i konflikten, og makrellen vart overfiska. Dette tyder på at realpolitiske omsyn framleis står sterkt i internasjonal ressursforvaltingspolitikk, også i møte med det som verkar som opplagte konsekvensar av klimaendringar. Fiskeriforvaltingsregime treng å konkretisere reglar for korleis ein skal handtere endringar i vandringsmønster, og korleis nykommarar til fisket kan inkluderast på ein konstruktiv måte. Slik unngår ein overfiske og framtidig bestandskollaps.
\end{abstract}

Nøkkelord: fiskeri $\cdot$ ressursforvalting $\cdot$ Arktis $\cdot$ klimaendringar

\footnotetext{
^Kontaktinformasjon: Olav Anders Totland, e-post: oatotland@fni.no

(C)2020 Olav Anders Totland. This is an Open Access article distributed under the terms of the Creative Commons Attribution 4.0 International License (http://creativecommons.org/licenses/by/4.0/), allowing third parties to copy and redistribute the material in any medium or format and to remix, transform, and build upon the material for any purpose, even commercially, provided the original work is properly cited and states its license. Citation: Olav Anders Totland (2020). Makrellkonflikten og strategisk klimafornekting. Internasjonal Politikk, 78(2): 142-166. http://dx.doi.org/10.23865/intpol.v78.1453
} 


\section{Introduksjon}

Det føregår mange store og små endringar i det marine miljøet; som auka pH-verdiar i havet, oksygenmangel og fiskedød og smelting av is i Arktis (Burkett et al., 2014, s. 190). I Atlanterhavet er særleg dei nordaustlege havområda blant dei raskaste til å bli varma opp (Sherman et al., 2013, s. 56). Det gjeld spesielt Norskehavet og havområda kring Island, Færøyane og Grønland (One Shared Ocean, 2017). I løpet av dei siste åra er ein blitt stadig meir klar over at sjølv små klimaendringar kan få store konsekvensar for vandringsmønsteret til fiskebestandar. Med endra vandringsmønster opnar det seg nye moglegheiter for statar som tidlegare ikkje har delteke i fisket, såkalla nykommarar. Endringane kan føre til at etablerte partar eller nykommarar ønsker å reforhandle fiskeriavtalene dei er del av. Etablert fiskeriforvalting blir dermed sett på ei stor prøve: Sjølve rammeverket til forvaltinga blir utfordra. Klarar ressursforvaltingsinstitusjonar å svare på desse utfordringane på ein konstruktiv måte, eller har dei store problem med å tilpasse seg endringane?

I den etablerte fiskeriforvaltinga er det mange interessentar: fiskeriforvaltingsorganisasjonar, interesseorganisasjonar, fiskeindustri og styresmakter. Det blir dermed mange synspunkt som må takast høgde for i fiskeriforvaltinga. Nokre av desse syna er motstridande og i konkurranse med kvarandre. Denne artikkelen vil sjå nærare på ei slik hending, den som vert kalla Makrellkrigen, eller makrellkonflikten. Makrellkonflikten var og er eit tydeleg døme på klare motstridande politiske og økonomiske interesser, knytt til det endra vandringsmønsteret til makrellen.

Konflikten starta seint i 2008 og ramma makrellforvaltingssamarbeidet i Nordaust-Atlanteren. Makrellen er ein verdifull fisk, og i EU er det berre sild det blir fiska meir av (Eurostat, 2017). Organisasjonen med ansvar for makrellforvaltinga er Den nordaust-atlantiske fiskerikommisjon (NEAFC heretter), og partane i makrellforvaltinga var Noreg, EU og Færøyane. ${ }^{1}$ Den felles avtala om makrellforvaltinga vert kalla kyststatavtala for makrell. Den vart vedteken i 1999, og partane då var Noreg, Færøyane og EU. Sannsynlegvis på grunn av klimaendringar endra makrellen vandringsmønster rundt 2006 og vandrar no lenger nord og vest. Makrell blir for det meste fiska i økonomiske soner, men betydelege mengder blir også fiska på opent hav. Island vart ein nykommar i makrellfisket i år 2006 (ICES, 2017, s. 9-10). Dette førte til at Færøyane ville reforhandle kyststatavtala. Noreg og EU gjekk ikkje med på dette. Det vart ikkje mogleg å einast om nye forvaltingstiltak med Færøyane i 2010, og makrellforvaltinga braut saman (Meld. St. 26 (2010-2011). Utan einigheit kring forvaltinga vart berekrafta til bestanden sett i fare. Korleis kunne ti år med forvaltingssamarbeid bryte saman så fort det kom ein ny spelar til bordet?

\footnotetext{
${ }^{1}$ Agreed Record of Conclusions of Fisheries Consultations between the Faroe Islands, the European Community, and Norway on the Management of Mackerel in the North-East Atlantic for 2009.
} 


\section{Olav Anders Totland}

For å forstå dette er det naudsynt å undersøke det institusjonelle rammeverket NEAFC er ein del av, og om partane i konflikten opplevde at dei kunne ignorere regimet og pliktene sine for å auke eigen økonomisk gevinst. Det er likevel viktig å presisere at det var makrellforvaltingsregimet innan NEAFC som opplevde eit samanbrot, og ikkje summen av alt samarbeid innanfor NEAFC. Ved å undersøke både det institusjonelle rammeverket rundt forvaltinga og dei ulike statanes taktikkar for å nå ønska resultat kan ein auke kunnskapen kring eit viktig tema:Vil framtidige klimarelaterte ressursforvaltingskonfliktar vere vanskelege å løyse, og kva skal til for å forebygge liknande konfliktar i framtida?

Makrellkonflikten har ikkje løyst seg, men i 2014 vart dei opphavlege partane einige om ei ny, felles forvalting. ${ }^{2}$ Island er framleis ikkje del av forvaltinga, og Grønland har også blitt aktive i makrellfisket. Makrellfisket vil neppe bli berekraftig før ein klarar å einast om ein felles forvaltingsplan.

Makrellkonflikten er interessant av fleire grunnar. Dersom ein snakkar om konfliktar kring ressursar, vil nok mange tenke på meir valdelege konfliktar, anten det handlar om tilgang på vatn, diamantar eller olje. Makrellkonflikten er eit døme på ein ikkje-valdeleg klimarelatert ressurskonflikt som ramma rike land i nord. Dersom vestlege demokrati ikkje klarar å handtere slike konfliktar på ein konstruktiv måte, kan det love dårleg for konfliktløysing andre stader i verda. Det er vidare mogleg å sjå konflikten som del av eit større konfliktknutepunkt i Arktis: Global oppvarming skjer raskare og med sterkare effekt i Arktis (IPCC, u.å.). Konsekvensen av dette er dramatiske endringar i arktisk klima og miljø. Eit ytterlegare poeng er at å drive med klimaforsking er komplekst og til tider prega av stor usikkerheit. Kompliserte ressurskonfliktar kan bli forverra av mangel på konsensus kring forskinga. I makrellkonflikten klarte ein ikkje å einast fullstendig kring forskinga, og dette leia til eit konsekvent overfiske fram til i dag. Med overfiske meiner ein at tilrådde kvoter bli sett til side, og at det blir fiska fleire tonn enn tilrådd. I denne konflikta vil det seie Det internasjonale havforskingsrådet (ICES heretter i teksten) sine tilrådde kvoter for makrell. Kort fortalt kom ueinigheita kring forskinga frå ulike tolkningar om årsaka til det endra migrasjonsmønsteret til makrellen: Var det forårsaka av klimaendringar eller av andre faktorar?

Dette tyder på at det regionale forvaltingsregimet fungerer dersom alle partar er einige på førehand, men at regimet raskt blir irrelevant dersom det er grunnleggjande ueinigheiter.

Ein studie av makrellkonflikten kan dermed gje ein peikepinn på korleis slike konfliktar kan arte seg. Denne artikkelen vil vise at NEAFC-regimet er svakt, og at det havrettslege rammeverket er til lite hjelp i slike konfliktar. Svake ressursforvaltingsregime er dårleg utrusta til à stå i mot krav frå nykommarar, og dersom konflikten kan knytast til klimaendringar, vil partane stridast om årsaksforklaringar. Dette er skadeleg for levande ressursars berekraft og kan ha negative konsekvensar for klimaforsking

\footnotetext{
${ }^{2}$ Agreed Record on A Fisheries Arrangement between the European Union, the Faroe Islands and Norway on the Management of Mackerel in the North-East Atlantic for 2014 to 2018.
} 
generelt. I sum kan dette tyde på at fiskeriforvaltinga er sårbare for nykommarar til forvaltinga, og særleg dersom ein ser dette i samband med klimaendringar.

Makrellkonflikten vert undersøkt frå fleire vinklar gjennom dokumentanalyse av konvensjonar, offentlege dokument, statistikk, rapportar og andre forskingsbidrag. Informasjon er også henta gjennom innsynsordninga til Nærings- og fiskeridepartementet og Utanriksdepartementet. Kjeldegrunnlaget er innhenta gjennom databasar og tidsskrift på nett. Det er også nytta ein god del nyhendekjelder, ettersom dette gjev eit innblikk i dei ulike statanes tilnærming til problemstillinga, både for eit innanrikspublikum og retta mot ein internasjonal arena. Statistikk er innhenta frå andre forskingsartiklar og frå relevante organisasjonar som ICES. Slutningane blir tekne på grunnlag av det som generelt blir kalla prosessporing. Det vil seie at forskar trekker både deskriptive og kausale slutningar frå kasusets datapunkt (Collier, 2011, s. 824).

Artikkelen vil først vise til ulike oppfatningar kring rolla internasjonalt samarbeid spelar i å løyse internasjonale utfordringar. Deretter vil internasjonale regime og havrettsprinsippa som er gjeldande i makrellkonflikten, bli skildra.

\section{Internasjonale institusjonars rolle i forvaltinga}

Innan fiskeriforvalting er det etablert eit omfattande internasjonalt rammeverk for å legge til rette for samarbeid. Dei aller mest sentrale rammeverka i fiskeriforvalting er havrettskonvensjonen og Opne hav-avtala (også kalla Fish Stocks Agreement), og desse konvensjonane er vedtekne gjennom $\mathrm{FN}$-systemet. Desse konvensjonane er formulert for å sikre eit ansvarleg og berekraftig fiske (Opne hav-avtala av 1995, fortale). Kvar einskild stat vil naturlegvis vere oppteken av å maksimere profitten i fisket staten deltek i. For å hindre at dette skal gå utover berekrafta til heile bestanden er det oppretta regionale fiskeriforvaltingsorganisasjonar (RFFO heretter, gjeld både eintal og fleirtalsformer av omgrepet). NEAFC er ein RFFO med ansvar for det nordaustatlantiske havområdet. RFFO sine oppgåver er blant anna å regulere kven som får delta i fisket, sette minimumsstandardar for fangstverksemd, gjennomføre vitskaplege undersøkingar og verte einige om beslutningsprosedyrar som sikrar effektiv implementering av bevaringstiltak. ${ }^{3}$ RFFO må derfor ha tilgang på god og nøyaktig forsking.

Med faste normer og reglar for korleis fiskerisamarbeid skal føregå, unngår ein konfliktar som potensielt kan skade fiskebestandar varig. Formålet med ressursforvalting er å unngå det som vert kalla allmenningens tragedie. Kort fortalt handlar tragedien om eit felles beite eigd av bøndene i ein landsby, og den er av avgrensa storleik. Det er forventa at alle bønder vil ha så mange beitedyr som mogleg på allmenningen (Hardin, 1968, s. 1244).

Det er rasjonelt for kvar bonde å auke talet på beitedyr for å auke profitten sin. Til slutt aukar alle bøndene talet dyr dei har på beite, og allmenningen går til grunne

${ }^{3}$ Opne hav-avtala, 1995, artikkel 10 (ledd b, c, g, j). 


\section{Olav Anders Totland}

(Hardin, 1968, s. 1244). Tragedien lærer oss at ressursutnytting utan berekraftigheit som prinsipp fører til kollaps.

Dersom ein fiskebestand kollapsar, er det ikkje lenger mogleg å tene pengar på han. Før bestanden kollapsar, er det derimot rasjonelt for fiskarane å fiske så mykje som mogleg. Fiskarar har dermed eit sterkt insentiv til å bryte med etablerte avtalar om fiskeriforvalting, særleg dersom det å respektere forvaltinga medfører tapt inntekt (Ásgeirsdóttir, 2008, s. 14-15).

Derfor trengst det mekanismar som kan straffe slik oppførsel (Young, 1998, s. 221).

Gjennom ulike former for åtferdsregulering (reglar, normer og andre mekanismar) søker det internasjonale samfunnet å unngå ein global allmenningens tragedie i samband med fiske. For å klare å fremme ansvarleg åtferd i fiskeria, trengst det reiskapar som tvingar dei involverte aktørane til å etterkomme avtalane (Hardin, 1968, s. 1247). Innan fiskeriforvalting er det eit utstrekt samarbeid mellom statar. Sjølv om statane ikkje formelt gjev opp suvereniteten sin, har fleire internasjonale regime makt til å endre statanes åtferd (Malnes, 2011, s. 21).

Eit internasjonalt regime blir gjerne definert som eit sett med ulike normer, reglar og prinsipp for korleis ein tek avgjerder (beslutningsprosedyrar), som aktørar innan eit saksfelt kan samle seg om (Krasner, 1982, s. 185).

Dersom mangel på koordinasjon fører til kostnadar som er svært ulikt fordelt mellom deltakarane, kallar ein det for eit vondarta problem. Då er det ikkje samsvar mellom ein aktørs oppførsel og gruppa som heilheit, og ein får eit suboptimalt utfall (Underdal, 2013, s. 24).

Under slike omstende blir internasjonale regime ein mogleg reiskap for å løyse utfordringa (Hasenclever et al., 2000, s. 16). I møte med vondarta problem må regime vere sterke. Regimets styrke blir gjerne vurdert ut ifrå i kor stor grad regimet kan innsnevre fridommen til den individuelle deltakaren (Underdal, 2004, s. 28).

Internasjonale regime kan ta form som internasjonale organisasjonar. Desse har gjerne kunnskap og juridisk kompetanse innan spesifikke saksfelt (Stokke, 2011, s. 273).

Internasjonalt samarbeid er sentralt i denne artikkelen. Det er derfor ønskeleg å kort skildre to kjende tilnærmingar som seier noko om moglegheiter og betydninga av internasjonalt samarbeid: ${ }^{4}$ nyliberal institusjonalisme og strukturell realisme. Retninga som meiner internasjonale regime spelar ei viktig rolle $\mathrm{i}$ å påverke statars samhandling på den internasjonale arenaen, blir gjerne kalla nyliberal institusjonalisme (Stokke, 2011, s. 274).Tilnærminga legg til grunn ei tru på at ein kan løyse konfliktar

\footnotetext{
${ }^{4}$ Det er fleire kjende tilnærmingar innan studiet av internasjonale relasjonar. Konstruktivismen t.d. legg vekt på det sosiale aspektet. Normer, sosiale samhald, idear og trusretningar påverkar aktørane på den internasjonale arenaen og igjen deira handlingar. Når tankesystemet endrar seg, så endrar det og dei internasjonale relasjonane. Alexander Wendt summerer denne ideen opp i utsegna «Anarchy is what states make of it» (Jacskon \& Sørensen, 2016, s. 162).
} 
gjennom institusjonar. Dei ulike internasjonale regima i verda hjelper statar å nå felles mål (Hasenclever et al, 2000, s. 7).

Realistar er opptekne av at makt er det viktigaste verkemiddelet i politikken (Mearsheimer, 2013, s. 72). Staten er ein rasjonell aktør, og kvar stat er ute etter å auke si makt samanlikna med andre statar. I dag vert retninga innan realismen som tek høgde for dette, kalla neorealisme eller strukturell realisme (Wendt, 1992, s. 395; Mearsheimer, 2013, s. 72). Det er sjølve strukturen i det internasjonale systemet som gjer at statar søker makt (Wendt, 1992, s. 395; Mearsheimer, 2013, s. 72). Det avgjerande skiljet mellom sterke og svake statar er maktressursar (Malnes, 2011, s. 39). I ei verd prega av strukturell realisme har avtalar, institusjonar og rettsreglar ei svak(are) stilling. Å delta i internasjonale regime er også i større grad ei «frivillig handling» (Fearon, 1998, s. 271).

I denne undersøkinga er det to nært beslekta regime som blir undersøkt. Det havrettslege regimet, med utgangspunkt i FN-konvensjonane, skapar eit rammeverk som RFFO skal operere innanfor.

RFFO-regimet er meir spesifikt innretta mot eit havområde og utfordringane der og har eigne prinsipp for styring. Desse prinsippa skal likevel vere i samsvar med havretten generelt.

NEAFC er sentral i denne artikkelen. Etter havretten har denne RFFOen mandat til å regulere fiskeriforvalting i Nordaust-Atlanteren, og dermed makrellen. NEAFCs mål er å fremme ein optimal bruk av fiskeressursane i NordaustAtlanteren og å oppfordre til internasjonalt samarbeid kring desse (NEAFC, 1980). NEAFC gjer det mogleg at statar som deler dette målet, kan opptre koordinert på den internasjonale arenaen. NEAFCs arbeid med å fremme presis kunnskap om bestandstørrelse, fangstmengder og berekraft kan auke sjansen for at statar respekterer ressursforvaltingsregimet. Slike tiltak aukar sjansen for at felles ressursforvaltingsregime klarar å overleve (Ostrom, 1992, s. 300). NEAFC kan dermed bidra til å motverke suboptimale utfall.

Makrellforvaltinga i NEAFC har altså eigne reglar, normer og prinsipp. Dermed er det riktig å karakterisere NEAFC som eit internasjonalt regime. Samhandling mellom to eller fleire internasjonale institusjonar i forsøk på å styre eit internasjonalt saksfelt vert kalla regimekompleks (Oberthür \& Stokke, 2011, s. 1) Makrellforvaltinga i NEAFC er dermed del av eit større regimekompleks, sidan det er del av det multilaterale regimet i NEAFC, bilaterale avtalar og havretten.

Det er altså ulike måtar ein kan tolke det internasjonale politiske systemet på, og kor stor makt regime har. Nedanfor vil rammeverket desse deltakarane er del av, diskuterast nøyare, og sjølve makrellkonflikten vil bli skildra i større detalj.

\section{Makrellkonflikten}

Makrellen er ein grensekryssande bestand med store verdiar D-vitamin og omega-3 (NIFES, 2015). Han er ein attraktiv matfisk og vert fiska kommersielt. Makrellen flyttar seg over store avstandar for å nå beiteområde og overvintringsområde. 


\section{Olav Anders Totland}

Fisket er sesongbasert, og rundt 50\% av makrellen vert no fiska i norsk, islandsk og færøysk sone (Nordic Marine Think Tank, 2015, s. 45). På grunn av dei store avstandane makrellen vandrar over, er det også mange interessentar i forvaltinga. Makrellen trivst i varmare hav, og nokre forskarar reknar med at dette speler ei rolle i det endra vandringsmønsteret (Hop \& Gabrielsen, 2013). Samtidig er det framleis fagleg ueinigheit kring dette (Spijkers \& Boonstra, 2017, s. 1838), noko analysen vil framheve.

Makrell vert fiska både i internasjonalt hav og i økonomiske soner. Etter havretten er det det fisket som går føre seg på opent hav, som RFFO kan regulere. Statar har suverene rettar i dei økonomiske sonene. I perioden 2008-2014 gjekk fisket først og fremst føre seg i økonomiske soner. Fisket har også auka i NEAFCs reguleringsområde (altså opent hav i Nordaust-Atlanteren). Island fanga heile 51956 tonn makrell på opent hav i 2017.5 Makrellfisket byr dermed på utfordringar som må løysast både i NEAFC og statane i mellom.

At makrellen har vandra lenger nord, har vore kjent sidan 2008. Forskarar ved Norsk Polarinstitutt hevda allereie i 2008 at makrell ville verte ein arktisk fiskebestand, og i 2013 kunne ein fiske makrell i Isfjorden på Svalbard (Hop \& Gabrielsen, 2013). Dei siste åra har også Grønland fått tilgang på makrell (Spijkers \& Boonstra, 2017, s. 1838) og auka fangsten sin dramatisk frå 62 tonn i 2011 til 54148 tonn i 2013 (ICES, 2017, s. 10).

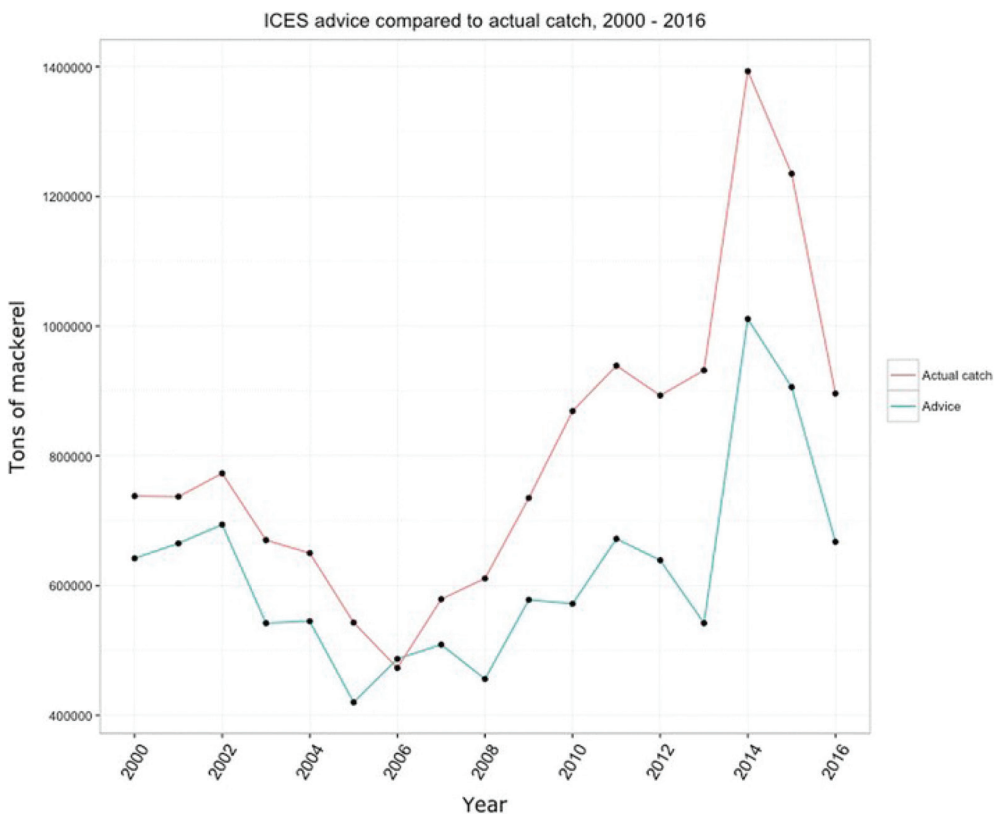

Figur 1 Frå Spijkers og Boonstra, 2017, s. 1841. Figuren viser at den faktiske fangsten fram til 2016 var langt høgare enn det ICES tilrådde han burde vere.

\footnotetext{
${ }^{5}$ Agreed Record of Conclusions of Fisheries Consultations between the Faroe Islands, the European Community, and Norway on the Management of Mackerel in the North-East Atlantic for 2017.
} 
Før 1996 vart det ikkje fanga ein einaste makrell på Island, og fram til 2006 vart det berre fanga små mengder. I 2006 auka fangsten vesentleg, og det vart fiska 4000 tonn makrell. I 2014 hadde dette auka til heile 170000 tonn (ICES, 2017, s. 9-10). Det er med andre ord lett å peike nøyaktig på kva tid makrellen vart tilgjengeleg for Island. Færøyane derimot har fiska makrell i betydelege mengder sidan 1988 (ICES, s. 9-10). Ut frå kyststatavtala for makrell av 1999 har Færøyane pleidd å få 5\% av makrellkvoten (Nielsen et al., 2010, s. 114).

Ved å inkludere Færøyane i ei multilateral avtale frå 1999 synte Noreg og EU at dei aksepterte Færøyane som relevant kyststat for makrellforvaltinga (Meld. St. 26 (2010-2011), s. 7).

Makrellfisket er av stor betydning for EU og Noreg. Makrellen har vore den mest verdifulle fisken for Storbritannia (World Fishing, 2014) og for Noreg den mest innbringande fisken etter torsk og sild (SSB, 2018).

I 2009 byrja kyststatavtala å breste. Noreg og EU gjorde krav på høvesvis $28 \%$ og $62 \%$ av totalkvoten (BarentsWatch, 2012). Fordelinga hadde vore omtrent slik sidan kyststatavtala vart inngått i 1999. Noreg og EU var hittil soleklart dei største spelarane i makrellfisket. Det vart ikkje sett på som hensiktsmessig å inkludere Island i klubben av relevante kyststatar for makrell. Då Island etterspurde vesentleg større kvotar under det årlege møtet i NEAFC, svarte EUs representant:

At this stage, certain Parties are not considered to be a relevant mackerel coastal State by the other three parties. Whilst I can sympathise to some extent, I must remind them of their obligations under international law to appropriately regulate their mackerel whether it be in national or international waters. (NEAFC, 2008a, s. 11)

Dette vart tolka av Island som at det ikkje ville bli aktuelt å inkludere dei som ein relevant kyststat for makrell, og at ein dermed kunne gløyme å få auka kvotane sine rettmessig. Island vart til slutt tildelt 0,31\% av makrellkvoten i 2009 (Nofima, 2014, s. 2).

Den største makrell-interessenten i EU er Storbritannia. Etter brexit vil dei største interessentane i EU verte Irland, Nederland og Spania (ICES, 2017, s. 10). Det er med andre ord mange interessentar i EU, og det kostar tid og energi å framforhandle løysingar innetter $i$ ein organisasjon eller stat.

Det kan vere svært vanskeleg å endre på avtalar når dei først er inngått. Statlege aktørar bruker nemleg mykje tid på å drøfte og forhandle med innanrikspolitiske aktørar (Putnam, 1988, s. 433). Dermed er det i utgangspunktet liten vilje til å reforhandle avtaler som har vore gjeldande over lang tid, slik som makrellforvaltinga.

Både Island og Færøyane er små, globaliserte øysamfunn med ei lita befolkning og forholdsvis høg grad av sysselsetting innan fiskeri. På Island er $7 \%$ av befolkninga sysselsett som fiskarar, mens på Færøyane er det heile 14\% (Hotvedt, 2010, s. 39-40). Fiske står for $40 \%$ av Islands eksportinntekt (Selmer, 2016) og $95 \%$ av 


\section{Olav Anders Totland}

Færøyanes. ${ }^{6}$ Ein tidlegare handelsminister frå Færøyane har karakterisert øygruppa som «[...] the most globalised territory on Earth. Everything we consume is imported, and everything we produce is exported»(Hannan, 2014). Inntil 2010 føregjekk det færøyske makrellfisket hovudsakleg i norsk farvatn (Nielsen et al., 2010, s. 113). Det er med andre ord av vesentleg interesse for begge nasjonar å auke fiske der dei kan.

Island fekk sin første invitasjon til kyststatsforhandlingane i 2009. Dette var kort tid etter at Island annonserte ein unilateral makrellkvote på heile 130000 tonn (IceNews, 2009). Det vart samtidig samanbrot i forhandlingane med Færøyane, som kravde ein kvote rett over den islandske (Nofima, 2014. s. 7). Dersom det skulle bli relevant med ei framtidig løysing, så stilte Færøyane krav om å få større kvote enn Island (Nofima, 2014, s. 2). Ein enda dermed opp med tre ulike forvaltingsopplegg frå 2009 av: EU og Noreg sitt, Island sitt og Færøyane sitt.

Resultatet var at ein venta at ICES sine tilrådde kvotar ville bli sprengt med heile $35 \%$, og at makrellbestanden ville falle under berekraftig nivå i 2012 (Cendrowicz, 2010). Berekraftsprinsippet vart dermed i praksis gravlagt. Konsekvensen av langvarig overfiske er godt kjent, og resultatet vil bli ein styrt kollaps i makrellfisket. Dette er grunnen til at allmenningens tragedie er ein så treffande metafor i ressursforvalting.

Det vart gjort fleire forsøk på å få til ei forhandlingsløysing:

Eit tilbod frå EU og Noreg om ei delt kvote på 14\% til Island og Færøyane vart avvist i 2011 og 2012 (Dagens Næringsliv, 2012). I Edinburgh i 2014, vart det også gjort forsøk frå EUs side om eit tilbod til Island på 11,9 \% av totalkvoten, men dette vart ikkje godteken av Norge. ${ }^{7}$ Forslag om ei ny, delt kvote på $20 \%$, vart heller ikkje godtatt (Bergensavisen, 2014). Konflikten var tilsynelatande heilt fastlåst. Tidlegare gode naboar sto no steilt på sitt og ingen såg ut til å ville fire på krava. I løpet av 2013 vart Færøyane utsett for økonomiske sanksjonar frå Noreg og EU, og desse bidrog sannsynlegvis til å gjere Færøyane meir villige til å forhandle. Det vart landingsforbod av færøysk makrell i EU og i Noreg (Nofima, 2014, s. 14), samtidig som Færøyane mista tilgang til å fiske makrell i norsk sone (Nielsen et al., 2010, s. 113). I 2014 aksepterte likevel Færøyane eit siste og større tilbod til Noreg og EU, og vendte tilbake til fellesforvaltinga.

I den nye kyststatavtala fekk Færøyane tredobla sin kvote, til omtrent 15\% del av totalkvoten for $2014-2018 .{ }^{8}$ Island sto derimot på sitt. Med ein meir diversifisert økonomi, og fleire kundar utanfor Europa, kunne dei klare seg gjennom sanksjonane frå EU og Noreg. (Fish Update, 2014)

I 2018 var situasjonen framleis at Island stod utanfor forvaltingsregimet, og det same gjer Grønland. Korleis var det eigentleg mogleg at eit forvaltingsregime gjennom 10 år kunne bryte saman ved første teikn på endra omstende?

\footnotetext{
${ }^{6}$ Ministry of Fisheries and Natural Resources (2018) Faroe Islands Fisheries E Aquaculture. Responsible management for a sustainable future.

${ }^{7}$ E-post frå Utanriksdepartementet om Islands reaksjonar på kyststatavtala. Originalbrev frå 13. mars 2014.

${ }^{8}$ Agreed Record on A Fisheries Arrangement between the European Union, the Faroe Islands and Norway on the Management of Mackerel in the North-East Atlantic for 2014 to 2018.
} 


\begin{tabular}{lc}
\hline Hending & År \\
\hline Første kyststatavtala og makrellregime & $1999-2009$ \\
Nykommaren Island aukar fisket av makrell kraftig & 2008 \\
Færøyane bryt med forvaltinga & 2010 \\
Ny kyststatavtale for perioden 2014 - desember 2018 & 2014 \\
\hline
\end{tabular}

\section{Havrettens utfordringar}

Til no har makrellkonflikten blitt skildra og eit teoretisk rammeverk har blitt presentert. Ettersom rammene i fiskerisamarbeid er avgrensa av havretten, må også dette internasjonale regimet skildrast i større detalj. Først etter at utfordringane ved havretten er analysert, kan ein svare på korleis dette påverkar styrken til NEAFC-regimet.

«Havet» er delt i ulike soner ut frå internasjonale konvensjonar. Denne artikkelen fokuserer på to soner, opent hav (internasjonalt hav) og økonomiske soner. I opent hav kan alle statar i utgangspunktet drive med skipsfart og fiske. ${ }^{9}$ Dette går heilt tilbake til tanken om mare liberum, det frie hav.

Kyststatar har rett til å opprette det som vert kalla eksklusive økonomiske soner. I slike soner har kyststaten suverene rettar til å utnytte, bevare og forvalte levande ressursar i vatnet. ${ }^{10}$ Slike soner er blitt oppretta av alle kyststatar (Jensen, 2008, s. 413). Ei økonomisk sone kan ikkje strekke seg lenger enn 200 nautiske mil frå grunnlinja. ${ }^{11}$

Dersom fiskebestandar i den økonomiske sona er vandrande eller langtmigrerande, skal relevante statar samarbeide om forvaltinga av den. Artikkel 61(2) og 63 i Havrettskonvensjonen og Artikkel 8.1 i Opne hav-avtala stiller desse krava til samarbeid (Ørebech, 2013, s. 350).

Fisk tek naturligvis ikkje omsyn til statlege grenser eller nasjonale forvaltingsopplegg i sitt vandringsmønster. Enkeltstatar og RFFO må derfor ta høgde for ulik oppførsel hjå dei relevante fiskebestandane. Dei bestandane som berre finst innan ein stats jurisdiksjonsområde, vert kalla eksklusive bestandar. Delte bestandar finst innan området til to eller fleire statar. Vandrande og langtmigrerande bestandar er både innan jurisdiksjonsområde til ein eller fleire statar, og dei held til på opent hav. Bestandar som er delte, langtmigrerande og/eller vandrande, vert kalla grensekryssande bestandar (Henriksen \& Hoel, 2011, s. 67), og makrellen er ein slik bestand. Fisket av grensekryssande bestandar kan ikkje gå føre seg heilt isolert. Overfiske i ei sone kan ramme ein annan stats fiske i denne staten si sone (Anderson, 1996, s. 465). Opne hav-avtala frå 1995 regulerer fangst av grensekryssande bestandar. Rettar medfører plikter. Særleg viktig er det at når kyststaten nyttar seg

\footnotetext{
${ }^{9}$ Artikkel 87, Havrettskonvensjonen, 1982.

${ }_{10}$ Artikkel 56, Havrettskonvensjonen, 1982.

${ }_{11}$ Artikkel 57, Havrettskonvensjonen, 1982.
} 


\section{Olav Anders Totland}

av sine rettar i den økonomiske sona, skal det også takast omsyn til andre statars rettar og plikter. ${ }^{12}$

Kyststaten er pliktig til å søke samarbeid med relevante, kompetente internasjonale organisasjona i arbeidet med å bevare dei levande ressursane (dersom dette er hensiktsmessig). Ei berekraftig ressursforvalting krev med andre ord samarbeid på tvers av relevante statar.

Ved forvalting av bestandar i opent hav skal kyststatane «ta hensyn til i hvilken grad kyststatene og de stater som fisker på det åpne hav, er avhengige av vedkommende bestander». ${ }^{13}$ I praksis betyr dette at kyststatar som fiskar makrell, skal delta i NEAFC. Dette er også tilfellet. Fangst i eiga sone skal ikkje skade bestanden som heilskap. Rovdrift er med andre ord forbode. Det er likevel ikkje nokre enkle praktiske retningslinjer for korleis dette samarbeidet skal gå føre seg (Henriksen \& Hoel, 2011, s. 69).

ICES har ei viktig rådgjevande rolle ved fastsetting av kvotar for fiskebestandar. ICES gjev anbefalingar til blant anna NEAFC og Europakommisjonen (ICES, u.å.). I utgangspunktet pleier NEAFC-deltakarane lytte til ICES sine råd. Kvoteordninga som blir brukt til å regulere kor mykje fisk kvar einskild stat får fange, vert kalla totalkvotar (TAC). EU og samarbeidsstatar (som Noreg og Island) skal bestemme kvotane for fiskebestandane kvart år (Europakommisjonen, 2017). Totalkvotane er naudsynte for å sikre at bestanden blir forvalta berekraftig gjennom heile vandringsmønsteret sitt (Henriksen \& Hoel, 2011, s. 68). For å kunne krevje del av totalkvoten burde staten vere allment akseptert som kyststat for den gitte bestanden. Ein stat skal i utgangspunktet få status som kyststat for ein fiskebestand dersom denne bestanden tilbringar tid innanfor denne staten si økonomiske sone. Då har fiskebestanden ei såkalla sonetilhøyrigheit, oppgitt i prosent (BarentsWatch, 2012). I Noreg er gjerne Hamre-modellen akseptert som utrekningsmåte.

For å finne ut sonetilhøyrigheita til ein bestand i Hamremodellen reknar ein ut biomassen (mengda) av bestanden og kor lenge (i gjennomsnitt) ein årsklasse av denne bestanden oppheld seg i den økonomiske sona (Hamre, 1993, s. 3). Det er likevel ikkje gitt at ein stat alltid vil føretrekke ein særskild måte å rekne ut sonetilhøyrigheit. Føretrekt måte å rekne ut sonetilhøyrigheit vil variere ut ifrå politiske omsyn.Mykje av konfliktpotensialet i makrellkonflikten spring ut i frå ulike tolkingar av omgrepa nemnt ovanfor.

Dei havrettslege prinsippa og reglane har mange punkt ein kan utfordre forvaltingsregimet på. Eit gjennomgåande fenomen ved internasjonale konvensjonar er at dei er ofte er vanskelege å handheve (Štulajter, 2017, s. 325). Suverenitet blir sjeldan gitt vekk, og tilslutning til regime er frivillig. Regimets evne til kollektiv respons på utfordringar er opp til kva som er akseptabelt for den minst entusiastiske deltakaren (Wettestad, 1999, s. 25).

${ }_{12}$ Artikkel 56, Havrettskonvensjonen, 1982.

13 Artikkel 7, Opne hav-avtala, 1995. 
Havrettskonvensjonen krev at dersom det er hensiktsmessig, skal kyststatar samarbeide med RFFO om å fastsette bevaringstiltak, slik at bestanden ikkje blir overfiska. ${ }^{14}$ RFFO har også fått makt til å gripe inn i bevaringa og reguleringa av fiskebestandar. Dermed er statane pålagt å følgje råda til RFFO. ${ }^{15}$ Det viser seg derimot at fråsegna "skal samarbeide» ikkje vert tolka strengt: I praksis betyr det at partane burde sette seg ned og forhandle. Statane er ikkje pliktige til å komme fram til konkrete avgjerder i forhandlingane (Hayashi, 1993, s. 249). Det er heller ikkje nokre enkle retningslinjer for korleis eit samarbeid skal gå føre seg (Henriksen \& Hoel, 2011, s. 69). Under prinsippet pacta tertiis nec nocent nec prosunt er det også slik at tredjepartsstatar ikkje er bundne av avtalar dei ikkje sjølv deltek i (Serdy, 2016, s. 3). Det vil seie at dei statane som samarbeider om bevaringstiltak, gier situasjonen meir gunstig for dei som ikkje deltek i forvaltinga.

Færøyanes avgjerd om å forlate forvaltinga kan henge saman med dette. Dersom ein står utanfor relevante forvaltingsopplegg, kan ein nyte godt av RFFOmedlemmane si (teoretiske) forsiktigheit og fiske meir sjølv. Dermed slepp ein unna $ø$ konomiske kostnadar knytt til forvaltinga. Dette vert kalla gratispassasjer-oppførsel. Ein gratispassasjer lar dermed vere å bidra til fellesskapet, men nyt goda av samarbeidet likevel.

At nokre statar vel å verte gratispassasjerar i fiskeriforvaltingsregime er eit kjent problem. Organisasjonen for økonomisk samarbeid og utvikling har hevda at i fiskeria er: "[the] open access nature of marine fisheries is the fundamental cause of poor economic performance and biological overexploitation (Serdy, 2016, s. 11). Sidan internasjonalt fiske baserer seg på prinsippet om havets fridom, er det vanskeleg å hindre gratispassasjeroppførsel.

Utfordringane til RFFO stansar ikkje der, fordi det viser seg at forvaltingsregime slit med å få deltakarane til å føye seg etter regima sine eigne reglar og vedtak.

RFFO er ikkje kjent for å vere effektive regime. Hallwood har undersøkt Sydnes og Cullis-Suzuki og Pauly sine komparative analyser av RFFO, og han viser at det er motstridande beskjeder i havretten. Deltakarstatane kan i praksis plukke og velje kva som er relevante reglar å følgje, og kva reglar dei vil ignorere (Hallwood, 2016, s. 131).

Forvaltingsregime bryt dermed saman fordi havretten er for svak og uklar. Dette gjer det mogleg for statar å utnytte eller ignorere havretten fullstendig. Plikta til å samarbeide om forvaltinga er alt for svak (Hallwood, 2016, s. 131). Eit hovudproblem med havretten er dermed at all tilslutning til forvaltingsregime er basert på

\footnotetext{
${ }_{14}$ Artikkel 61 (2), Havrettskonvensjonen, 1982: «Kyststaten skal under hensyntagen til de beste tilgjengelige vitenskapelige data gjennom passende bevarings- og forvaltningstiltak sikre at opprettholdelsen av de levende ressurser i den eksklusive økonomiske sone ikke settes i fare av overbeskatning. Når det er hensiktsmessig, skal kyststaten og kompetente internasjonale organisasjoner, det være seg subregionale, regionale eller globale, samarbeide for dette formål.»

${ }^{15}$ Artikkel 21, Opne hav-avtala, 1995.
} 


\section{Olav Anders Totland}

frivilligheit. ${ }^{16}$ Havets fridom sikrar alle tilgang, samtidig som havretten seier ein er pliktig til å samarbeide. Det ser likevel ut til at prinsippet om havets fridom, trumfar havretten.

Oppsummert så inneber havretten moglegheiter, rettar og plikter for statar. Det blir stilt krav om å delta i RFFO og å einast om forvalting i desse. Det har derimot vist seg å ikkje stemme med røynda. Havretten er i praksis vag nok til å la partar tolke situasjonar ulikt og vektlegg «krav» eller «plikt til» å gjere noko svært ulikt. Dette opnar opp for at dei regionale regima, her representert ved NEAFC, kan ha store svakheiter.

Kjelda til eventuelle svakheiter er berre mogleg å forstå ved først å drøfte det grunnleggjande internasjonale regimet i fiskeria, nemleg havretten.

\section{Svake regime og nykommarproblemet}

Internasjonale regime vert stifta for å svare på ei internasjonal utfordring. Det er derfor ønskeleg at regimet skal vere funksjonelt. Eit viktig spørsmål i vurderinga om regimet er funksjonelt, blir dermed spørsmålet om det er sterkt. Eit regimes styrke er ein viktig faktor i regimets effektivitet. Eit sterkt regime handlar kollektivt, og det tillet minimalt med individuell råderett. Desentralisert maktstruktur kan tyde på at regimet er svakt (Underdal, 2004: 29). Det som er sikkert, er at dersom eit regime skal vere sterkt, må det ha tydeleg makt til å innskrenke oppførselen til deltakarane. Det skjer altså gjennom reglar og normer for kva som er lovleg og tillatt oppførsel (Underdal, 2004, s. 29).

Eit viktig spørsmål er korleis NEAFC-regimet kan synleggjere styrken sin. Sterke regime tillet ikkje avvikande oppførsel og har sentralisert makt (Underdal, 2004, s. 29). Ettersom det er legitimt at kyststatane som har rett til makrellfiske skal verte einige i NEAFC om forvaltinga, bør ein kunne forvente at NEAFC kan handheve reglane i havrettskonvensjonen og Opne hav-avtala og dessutan eigne vedtak.

Er dette tilfelle, eller er det dei individuelle deltakarane som sit med makta? Det er dei relevante kyststatane som får bestemme kor mykje av kvoten som skal fiskast i den økonomiske sona, og kor mykje som skal fiskast på opent hav (Ørebech, 2013, s. 347).

Kvotefordelinga skal i utgangspunktet vere basert på ICES sine anbefalingar om totalkvote. Alle kyststatar skal i utgangspunktet prøve å nå avtalar og forvaltingstiltak for bestanden, og «sørge for at disse tiltak ikke har skadeleg innverknad på de levende ressurser i havet som helhet». ${ }^{17}$

Her møtte forvaltingsregimet på eit stort og opplagt problem etter kvart som fiskebestanden endra vandringsmønster: Island var ikkje anerkjent som relevant kyststat. EU sa i 2008 at det ikkje var ønskeleg å inkludere fleire partar i avtala, og

${ }^{16}$ Artikkel 8, Opne hav-avtala, 1995.

17 Artikkel 7, Opne hav-avtala, 1995. 
det var ikkje aktuelt med «any unjustifiable unilateral measures by current Coastal States» (NEAFC, 2008a, s. 11). Island var trass alt ein heilt ny spelar i forvaltinga. Det var likevel akkurat dette som hende.

Gratispassasjerar i forvaltinga skapar mykje bry for deltakarane. Utan garantiar om at andre deltakarar i forvaltingsregimet framleis vil respektere forvaltinga, og ikkje fiske meir enn ein blir einig om, så blir det vanskeleg å få til eit inkluderande samarbeid. Den einskilde deltakaren opplever nemleg eit kortsiktig tap ved å respektere forvaltinga. Gratispassasjerar tener på dette og haustar gevinsten av forvaltinga, ettersom det blir meir fisk tilgjengeleg (Serdy, 2016, s. 31). NEAFC-regimet klarte ikkje å endre oppførselen til nokon av partane, og dette gjaldt både for partane innanfor og utanfor makrellregimet.

Svak handheving er noko som plagar heile RFFO-systemet. Mange RFFO kan berre blir einige om vedtak som $i k k j e$ snevrar inn suvereniteten til deltakarane. Vidare kan partane som har evne til å fatte vedtaka, også «reservere» seg mot dei (Hallwood, 2016, s. 131-132). Dette prinsippet gjeld også sjølv om ein bruker fleirtalsordningar for å få gjennom vedtaka.

Konsekvensen av denne organiseringa blir at deltakarane, trass i at dei har signert havrettskonvensjonen og Opne hav-avtala, ikkje treng å endre åtferd med mindre dei sjølv ønsker det (Hallwood, 2016, s. 132).

NEAFC bruker ei ordning der vedtak må ha støtte frå $2 / 3$ av medlemsstatane for å bli vedtatt. Det er likevel mogleg for usamde partar å klage på vedtaka, og etter at klageperioden er over så treng dei ikkje etterkomme dei (NEAFC-konvensjonen, 1980). Island nytta seg av at det var mogleg å protestere $\mathrm{i}$ tvisten om utdeling av makrellkvotar (NEAFC, 2008b, s. 12).

Har dei etablerte «relevante» kyststatane då «rett» til å utelukke nykommaren Island frå forvaltinga? Ikkje ifølgje Opne hav-avtala. Dei etablerte statane skal ta omsyn til «behovene i fiskerisamfunn ved kysten som i hovedsak er avhengig av å fiske etter bestandene; $;{ }^{18}$ og «behovene i kyststater hvis økonomi i overveldende grad er avhengig av utnyttelsen av de levende ressurser i havet». ${ }^{19}$ Desse punkta er relevante både for Island og Færøyane.

Det er likevel lite truleg at Noreg og EU vil anerkjenne at Island er særleg avhengig av ein fiskebestand som dei nyleg har starta å fiske. Noreg og Storbritannia har langt større erfaring med makrellfiske i eit historisk perspektiv enn det Island har. Det som likevel er sikkert, er at Opne hav-avtala ikkje gjev etablerte statar moglegheita til å blankt avslå nykommarar sine krav om tilgang til fiske (Henriksen \& Hoel, 2011, s. 73). Det burde nemnast her at historisk fiske også er ein vanleg måte å utrekne sonetilhøyrigheit på, og her kjem Island naturligvis dårlegare ut enn Noreg, EU og Færøyane.

Problemet er at internasjonale regime ikkje berre er rasjonelle organisasjonar, men også sosiale institusjonar. Det vil seie at i regimet blir roller fordelt og partane

${ }_{18}$ Artikkel 11, Opne hav-avtala, ledd d.

${ }_{19}$ Artikkel 11, Opne hav-avtala, ledd e. 


\section{Olav Anders Totland}

må tilpasse seg ulike normer. Normene i regimet fortel deltakarane kva som er akseptabel oppførsel, og kva slags fordelar ein kan forvente ved å delta (Stokke, 2011, s. 273). Heilt konkret er dette knytt til korleis ein fordeler kvotar av ulike fiskebestandar, korleis ein gjennomfører praktiske undersøkingar og anna forsking på fiskeria. Dermed vil tidlegare praksis til slutt bli oppfatta som ei (uformell) norm. Når Noreg og EU venta seg 90\% av den årlege makrellkvoten, så er det dette som har skjedd. Det var dermed venta at Færøyane og Russland skulle vere nøgde med 5\% kvar (Hotvedt, 2010, s. 25). Slepp nykommarar til i forvaltinga, vil bestanden sannsynlegvis bli mindre berekraftig nytta. Jo fleire som skal dele på kaka, jo mindre blir kakestykka.

Det kan tyde på at medlemsstatane er av den oppfatninga at å delta i regimet er «frivillig», og at det ikkje inneber særleg risiko å drive med overfiske. Nykommarproblematikken blir faktisk skildra som den største utfordringa for havretten generelt (Serdy, 2016, s. 3). Ein betinga fornybar ressurs som makrell fører til auka konkurranse blant deltakarane om å få tilgang til han. Maktforholdet synest å vere svært ulikt mellom partane i makrellkonflikten. I tillegg vil ein stats auka kvote i utgangspunktet føre til at ein annan part taper del av sin kvote. Dette er kjenneteikn på vondarta problem. Vondarta problem stiller eit regime overfor store prøvelsar.

Nykommarproblemet er heilt klart eit døme på vondarta problem. Dersom ei løysing på eit problem legg til grunn einigheit blant partane, kan ein parts gevinst berre forbetrast dersom det ikkje går på kostnad av nokon annan part (Underdal, 2011, s. 253). I makrellkonflikten vil løysingar sannsynlegvis alltid gå på kostnad av ein anna part, dersom ein skal ta omsyn til ei berekraftig utnytting av ressursen.

Analysen har hittil vist at forvaltingsregimet for makrellen er svakt, og at nykommarar lett kan utfordre eit slikt regime. Eit svakt regime kan ikkje stanse unilaterale tiltak frå deltakarane, ettersom makta ikkje er sentralisert. I det heile så verkar fråsegna om "The closer a regime comes to saying "anything goes», the weaker it is (...)", til å stemme i skildringa av NEAFC (Underdal, 2004, s. 29). Eit svakt regime betyr likevel ikkje at regimet er fullstendig irrelevant. Under heile konflikten er det diskusjonar kring kvotane i NEAFC, og partane argumenterer for kvifor deira syn er riktig. Sidan NEAFC-regimets mål om eit berekraftig fiske (regimets norm) kan utfordrast, så vil dette prege forhandlingane mellom aktørane i konflikten. Dette tyder på at det ikkje er ein avgjerande faktor som forklarar makrellkonflikten: Det internasjonale regimet er svakt, men ikkje irrelevant. Statane bruker makt og realpolitikk, men ønsker også å ta diskusjonane i internasjonale forum. Det internasjonale regimet, NEAFC, har heilt klart ein grad av legitimitet.

I siste del av analysen vil det verte argumentert for at usikkerheita knytt til klimaendringane fungerer som ein ekstra konfliktskapande dimensjon. Partane bruker forsking på ein strategisk måte for å legitimere sine eigne syn på konflikten.

I denne konflikten er klimaendringar og forsking på slike endringar heilt sentralt. Analysen vil vise at usikkerheit kring forskinga pregar forhandlingane mellom statane. 


\section{Strategisk bruk av og politisering av forsking}

Faktaopplysningar i forsking er til tider meir verdilada enn ein skulle tru. På eiga hand er det vanskeleg for nye fakta å endre verdiane til aktørar med motstridande interesser (Sarewitz, 2004, s. 386). Det er vanskeleg å kople forsking frå den politiske konteksten og samfunna (staten) som forskarar høyrer til. Særleg innan klima- og miljøforsking har interessentar klare preferansar for om dei stolar på visse aktørar eller ikkje (Sarewitz, 2004, s. 386).

Dermed burde RFFO, som «nøytrale arenaer» for interessentane, kunne legge til rette for ei berekraftig forvalting. RFFO har ei sentral rolle i å auke kunnskap om bestandane som vert forvalta. Dette heng sterkt saman med formålet til RFFOregimet og NEAFC-regimet: å sikre ei berekraftig nytting av marine levande ressursar. Ei berekraftig forvalting er heilt avhengig av at partane kan bli einige om vitskapen knytt til klimaendringane. Ein aukar kunnskap ved å ta i bruk dei mest moderne og nøyaktige vitskaplege dataa om fisket. Dette gjeld ikkje berre på det opne havet, men også i dei økonomiske sonene. ${ }^{20}$ Det er fleire måtar å bidra til å auke kunnskapsnivået i eit forvaltingsregime. Det er vanleg å giennomføre ulike typar undersøkingar for å avgjere utbreiing og størrelse på relevante bestandar. Ofte deler statane på ansvaret og samarbeider om undersøkingane. Noreg og EU hadde ansvar for å gjennomføre undersøkingar av makrellegg. Island og Færøyane, i lag med Noreg, hadde ansvar for trålarundersøkingane (Spijkers \& Boonstra, 2017, s. 1840).

I 2009 såg ein nokre av dei tidlegaste ueinigheitene kring både distribusjon og mengde av makrellen. Spørsmålet blir om ueinigheitene er knytt til sjølve forskinga, eller om det er strategiske vurderingar som gjer det vanskeleg å einast.

Som nemnt viser undersøkingar at makrellen gyter lenger vest og nord enn før. Fangsten av makrell går stort sett føre seg lenger nord enn før (ICES, 2014, s. 20). Det er særleg to spørsmål ein stridest om knytt til dette: Kor lenge kjem skiftet til å vare, og kva er drivkrafta bak det? Slike forskingsspørsmål er av stor relevans. Havretten stiller krav om at statar i forvaltinga er pliktige til å ta i bruk dei beste tilgjengelege vitskaplege dataa i vernet av ressursane sine. ${ }^{21}$

Først kan ein nemne at partane ikkje var einige kring sjølve drivkrafta bak skiftet i makrellutbreiinga. Det er to heilt ulike synspunkt som er sentrale: Det første handlar om at makrellbestanden er svært sunn og dermed er unormalt stor. Dermed treng makrellen større beiteområde enn tidlegare, og det er berre eit spørsmål om tid før normaltilstanden kjem tilbake. Denne forklaringa føretrekker EU og Noreg (Gänsbauer et al., 2016, s. 101).

Den andre forklaringa lener seg på klimaendringar (Gänsbauer et al., 2016, s. 101). Det relativt dramatiske skiftet i vandringsmønsteret på kort tid førte til ei reell forvirring og usikkerheit for dei relevante kyststatane. Dersom det er knytt stor

\footnotetext{
${ }^{20}$ Artikkel 61, Havrettskonvensjonen, 1982.

${ }^{21}$ Artikkel 61, Havrettskonvensjonen, 1982.
} 


\section{Olav Anders Totland}

usikkerheit til forvaltinga, kan visse aktørar velje å ignorere, misbruke eller skjule relevant informasjon (Polasky et al., 2011, s. 402). FNs klimapanel kan slå fast at hav vert varma opp seinare enn landområde, men at hava framleis vil bli varmare, ikkje kaldare. I Arktis vil denne oppvarminga sannsynlegvis også vere to til tre gongar høgare enn det globale gjennomsnittet (IPPC, 2018, s. 4). Ein kan dermed anta at det er meir realpolitiske omsyn som vert tekne når EU og Noreg argumenterer for at makrellskiftet berre er midlertidig.

I byrjinga stilte Noreg og EU spørsmål ved heilt grunnleggande informasjon i makrellkonflikten: Var det eigentleg makrell som vart fanga av Island? Statistikken som Island presenterte til NEAFC, kunne ikkje stemme. Ein islandsk kvoteforhandlar kunne fortelje at Noreg og EU hevda det ikkje fanst makrell i islandsk farvatn. «[...] We replied «there must be mackerel there, we have been catching mackerel» [EU og Noreg seier] "well, it's probably more herring that you claim is mackerel» (Spijkers \& Boonstra, 2017, s. 1846). Denne haldninga gjorde seg særleg gjeldande rett etter skiftet i vandringsmønsteret og i løpet av det første året (2008) av makrellkonflikten.

Årsaksforklaringa på makrellens endra vandringsmønster har heilt klare og viktige implikasjonar i ei eventuell ny fordeling av bestanden. Det er tydeleg at det er til Islands og Færøyanes beste dersom det blei allment akseptert at klimaendringar er den underliggande grunnen for skiftet. Varmare hav er ein relativt permanent tilstand. Permanente endringar fører til varige endringar i makrellens utbreiing. Implisitt er dette eit sterkt argument for å få auka (for Færøyanes del) og legitime/rettmessige (for Islands del) kvotar av makrellbestanden. Likeins vil det vere til beste for Noreg og EU å hevde at endringa er midlertidig. Det er ikkje noko poeng å sleppe nykommarar til, med alle rettar det inneber, dersom det går an å vente på at «normalen» skal returnere. Dersom Island først får ein legitim (stor) del av makrellkvoten, vil det bli vanskeleg eller umogleg å gå tilbake på dette dersom mønsteret endrar seg igjen.

Ein representant frå den islandske fiskerinæringa uttalte seg slik:

They [the Norwegians] have been quite open about their view that [the mackerel shift] is only a temporary thing. I guess that's one of the things that's driving their policy, that they're not going to give in and give us a piece of something that we won't have a piece of in the future. (Spijkers \& Boonstra, 2017, s. 1842)

Derfor er det meir økonomisk gunstig å argumentere for at makrellen berre sporadisk og tilfeldig vandrar til islandsk farvatn. I Hannesson (2013) skildrar ein ulike scenario for makrellens vandring og ulike strategiar Noreg og EU kan bruke for å hindre makrellen frå å vandre i store mengder til Island og Færøyane. Desse taktikkane er av fysisk sort, som t.d. strategisk overfiske i nokre økonomiske soner for å svekke forhandlingsposisjonen til Island og Færøyane. Kort oppsummert er argumentet slik: Er bestandens vandringsmønster avhengig av størrelsen, kan Noreg og EU fiske såpass at det ikkje vandrar makrell til islandsk og færøysk sone. Då blir deira forhandlingsposisjon svak (Hannesson, 2013, s. 4). 
Dersom makrellen berre tilfeldigvis vandrar inn i Islands og Færøyanes sone, veit ikkje Noreg og EU når dette skjer. Då blir forhandlingsposisjonen til øystatane sterk (Hannesson, 2013, s. 5). Desse taktikkane vart ikkje tekne i bruk. Det heng saman med at det sistnemnde dømet er det som liknar mest på situasjonen i dag, og då har Noreg og EU eit insentiv til å «akseptere» dei unilaterale kvotane i staden for å inngå kompromiss (Hannesson, 2013, s. 5).

Noregs «offisielle» syn på endringa i makrellens vandringsmønster forklarar derfor skepsisen mot å inkludere Island som kyststat for makrell. Ettersom makrellen berre midlertidig har vandra til Island og Færøyane, så kunne desse ikkje forvente å ta del i makrellfisket. "We don't know if there's going to be mackerel next year in Iceland", vart islendingane fortalt av norske forhandlarar (referert i Spijkers \& Boonstra, 2017, s. 1844). Det vart vidare tvilt på dei fleste argumenta Island og Færøyane fremma kring makrellens bruk av deira farvatn: Island og Færøyane hevda begge at makrellen legg på seg betydeleg i vandringa gjennom deira økonomiske sone. Det er fordi han et betydelege mengder av byttedyr i desse sonene.

Makrellen la først på seg 43\% av vekta si i islandsk sone (Óskarsson, 2012, s. 8). Islands ambassadør til EU, Thorir Ibsen, hevda vidare at «25 prosent av makrellen svømmer inn $\mathrm{i}$ islandsk sone hvor de øker vekten sin med 60 prosent, så vi må få vår rettmessige del av dette fiskeriet» (referert i Vartdal, 2012).

I færøysk sone vart det hevda at makrellen dobla vekta si (Sunnmørsposten, 2012). Noreg og EU vart ikkje overbeviste: «Iceland made their own version about [mackerel] weight gain and zonal attachment.» (...) (Spijkers \& Boonstra, 2017, s. 1843). Det er likevel ikkje direkte bevist at makrellen påverkar det islandske økosystemet særleg, sidan han i liten grad har overlappande diett med t.d. sild (Óskarsson, 2012, s. 9).

Hadde det vore ei klar overlapping mellom diettane til makrell og sild, kunne kanskje Island med større legitimitet argumentert for å få ein stor del av kvoten. Makrellvandringa ville jo då direkte påverka andre marine levande ressursar som Island nyttar seg av.

Det er ikkje heilt opplagt kor mykje makrell som faktisk migrerer til nye farvatn, og kor stor påverknad dette har for dei marine økosystema til Færøyane og Island (Óskarsson et al., 2012, s. 11-12). I ei undersøkinga av Pinsky \& Fogarty såg ein på fiskebestandar som vandra lenger nord grunna klimaendringar. Dette førte til at fisket blei intensivert med fordelaktige resultat for lokalsamfunna (Pinsky \& Fogart, 2013, s. 887). Det er likevel ikkje nødvendigvis positivt, sidan endringa i vandringsmønsteret gjev etablerte fiskarar og styresmakter insentiv til å overfiske bestanden, før han forsvinn utanfor rekkevidde. Denne problemstillinga blir forsterka dersom dette også skjer over ulike økonomiske soner, slik som i makrellkonflikten (Pinsky \& Fogarty, 2013, s. 890).

Den forskingsmessige usikkerheita har heilt tydeleg implikasjonar for kva Noreg og EU meiner er riktig sonetilhøyrigheit til (særleg) Island. Ei utfordring med å rekne ut sonetilhøyrigheit er at det ikkje finst klargjorde, allment aksepterte prinsipp. Skal ein bruke Hamre-modellen, eller skal ein legge til grunn andre måtar å rekne på? 


\section{Olav Anders Totland}

Det kan t.d. vere å ta omsyn til gyteområde eller til fordelinga av unge og vaksne individ. Skal beiteområde og overvintringsområde vektast ulikt? (Nordic Marine Think Tank, 2015, s. 58). Dersom ein skal bruke data i vurderingar frå kommersielle aktørar, er det alltid ein sjanse for feilrapportering. Dersom ein bruker data frå forskingstokt, er desse ofte berre tilgjengelege for ein bestemt sesong og for berre ein del av bestanden (Nordic Marine Think Tank, 2015, s. 61).

Dette er viktige spørsmål med reelle konsekvensar for forvaltinga.

ICES har rapportert om moglege skeivheiter («bias») i datagrunnlaget sitt når det gjeld makrellen i Nordaust-Atlanteren. Underrapportering av fangst er eit velkjent fenomen (ICES 2014, s. 14). Det er også mogleg at det det har skjedd andre feil under identifiseringa av makrellegg. Det kan påverke forskarars forståing av bestandens faktiske utbreiing i tid og rom, og av kor mykje makrell som faktisk vart landa under undersøkingsperioden (ICES, 2014, s. 13, 15, 16). Om ikkje anna så kan EU og Noreg bruke slike utsegner til å styrke sine argument om at skiftet ikkje kjem av klimaendringar.

Vidare vart forskarar overraska av kor tidleg makrellen starta å gyte, og at bestanden verka unormalt stor. Dette kunne observerast i 2010 og igjen i 2013. Årsaka kunne nok koplast til klimaendringar, men ei forklaring kunne også vere at beiteforholda i Norskehavet var blitt forverra (Óskarsson, 2012, s. 2). Konsekvensen av desse funna var at fleire stilte spørsmål ved om ikkje makrellbestandens størrelse var blitt vesentleg undervurdert (ICES, 2014, s. 38).

Ei berekraftig forvalting var ifølgje fiskeriminister Jóhannsson heilt avgjerande for at Island skal delta i ei kyststatavtale. ${ }^{22}$ Likevel sette Island unilaterale kvot og bidrog på den måten til at ICES sine råd vart vidare sprengt.

Det same gjorde Færøyane, og EU brukte argumentet om at fisket ikkje var berekraftig til å rettferdiggjere økonomiske sanksjonar mot Færøyane (Gänsbauer et a., 2016, s. 101). Fiskaranes talsmann på Færøyane i 2010, Jògvan Jespersen, meinte at når EU og Noreg seier at det var Færøyane og Island som braut samarbeidet, så snur dei, saka på hovudet. Noregs og EUs norm om at $90 \%$ av ICES tilrådde kvotar skal gå til dei, gjer at fisket ikkje lenger er berekraftig (Ny Tid, 2010). Gänsbauer et al. undersøkte vidare haldningane til aktørar innan fiskeri i Nordaust-Atlanteren, og ein av variablane i undersøkinga var «skepsis til forsking». Eit av funna var at Færøyane tvilte på at forsking frå andre statar ikkje var politisk motivert. Det same gjaldt fiskeriindustrien generelt (Gänsbauer et al., 2016, s. 101).

Kompleksiteten kring kva som er den faktiske, objektive sanninga, gjer det altså mogleg for aktørar å danne seg eit eige bilde av situasjonen, avhengig av kva institusjonell og politisk kontekst dei beveger seg i. Det er ikkje berre ein politisk strategi å velje nokre faktaopplysningar ein stolar på. Alle val av fakta er nemleg selektive, fordi valalternativa ein har no, kjem an på ei tidlegare kjede av val (Sarewitz, 2004,

22 E-post frå Utanriksdepartementet, vedlagt omsett artikkel. Artikkelen vart publisert i avisa Morgunblaðið, 15. mars, 2014. 
s. 90). Dette er ikkje ei problemstilling ein møter på berre i fiskeriforvalting. Den same utfordringa, om enn mykje vanskelegare å løyse, møter ein på i alle spørsmål om globale endringar og i spørsmål om korleis ein skal ta riktige val. Den riktige måten å handtere slike utfordringar på, er å samlast om felles løysingar som skapar tillit mellom deltakarane. Slik aukar ein også sjansen for god styring (Polasky et al., 2001, s. 402).

\section{Konklusjon}

Uansett kva slags forvaltingsopplegg ein planlegg, må ein ta høgde for klimaendringane. Ein treng derfor forvaltingsopplegg som har evne til å raskt tilpasse seg eventuelle endringar i miljøet (Lawler et al., 2010, s. 41). Dette står i kontrast til organiseringa av RFFO. Erfaring viser at RFFO ikkje klarar å forvalte grensekryssande bestandar godt nok. Bevaringstiltaka kjem for seint, er upassande for konteksten og har svak effekt. Generelt sett så har RFFO mange utfordringar når dei skal løyse kollektive problem (Serdy, 2016, s. 16). Dette heng saman med argumentet om at statar prioriterer først og fremst kortsiktig økonomisk gevinst. Sjølv om alle partar var opptekne av berekraft, vart fisket intensivert. Kvifor var det ingen av partane som sa "stopp»? Ein viktig del av forklaringa kan vere at dei faktiske forholda var så gunstige at det ikkje var ein «reell» frykt for bestandskollaps.

Makrellbestanden auka i tidsperioden, trass i at det føregjekk overfiske. Det var store årsklassar og rekruttering i heile perioden 2008-2018. Makrellkonflikten viser at det er stort konfliktpotensial rundt forvaltinga. Det er særs vanskeleg å forutsjå endringar i fiskebestandar før dei skjer, og dette er gjer forvalting vanskeleg (Wilson, 2006). I situasjonar der ein er ueinige om kva modellar som er relevante å bruke $i$ konfliktar, er det ein stor fare for at nokre aktørar er villige til å utnytte forskinga til sin eigen agenda (Folke et al., 2007, s. 28).

Denne undersøkinga har vist at to problem innanfor internasjonal regimeteori og fiskeriforvalting generelt kan bidra til å kaste lys over makrellkonflikten: problemet med eit svakt regime og problemet med vitskapleg uvisse. Analysen viser at NEAFCs makrellforvaltingsregime ikkje hadde sentralisert makt, og dermed ikkje evne til å sanksjonere deltakarane i det. Då ein nykommar i makrellforvaltinga dukka opp, førte den ibuande svakheita i regimet til at det braut saman. Havretten har svake påbod om korleis statar skal oppføre seg i RFFO. Nykommarar er særlege utfordringar for internasjonale regime, ettersom involverte interessentar svært sjeldan reduserer eigne kvotedelar. NEAFC-regimet var likevel framleis gjeldande, sjølv om kyststatavtala og det makrellforvaltingsregimet den oppretta, braut saman.

Deltakarstatane prøvde dermed å legitimere overfor kvarande sine syn på kva som var ei rettmessig fordeling av makrellen. Dermed opna dei institusjonelle problema opp for meir realpolitiske vurderingar av forhandlingane. Makrellkonflikten kan tydeleg koplast til spørsmål om klimaendringar, og ein kunne dermed bruke forsking strategisk for å prøve å stenge ute andre partar. Sjølv om Færøyane valde å komme tilbake til forvaltinga, så løyste ikkje konflikten seg fullstendig. Island står 


\section{Olav Anders Totland}

framleis utanfor, og fisket har ikkje vore berekraftig. For første gong sidan 2007 er makrellbestanden no under nivået for berekraftig utnytting (ICES, 2018b, s. 1). Vi ser altså at makrellkonflikten kan forklarast ikkje berre av eit svakt regime, men også av ei underliggande vitskapeleg usikkerheit som gjev ekstra brensel til konflikten.

Det kan vere utfordrande at klimaforsking blir brukt til å legitimere det eine eller det andre synet på kven som har rett til ressursar. Det er ikkje uvanlig i politikk å bruke forsking til å legitimere krav, men klimaforsking kan vere komplisert og kontroversiell. Dette kan i verste fall minske legitimiteten til ein svært viktig del av forsking på levande ressursar. Dette kasuset viser at ressursforvaltingskonfliktar har høgt politisk konfliktpotensial, og det relevante regimet hadde lita påverknadskraft. Kva skjer dersom slike konfliktar oppstår mellom meir autoritære statar, eller statar med lite interesse i og respekt for internasjonale organisasjonar? Både FN-systemet, EU-systemet og andre former for internasjonale regime er under auka angrep frå ulike samfunnsgrupper. Det er ikkje gitt at alle statar vil fortsette med støtte til internasjonale organisasjonar. Dersom internasjonale regime også verkar makteslause i forvaltingskonfliktar, kan tilliten til desse organisasjonane forvitre.

Det verkar tydeleg at NEAFC treng større mandat til å gripe inn i kyststatsforhandlingane. Det må vere heilt konkrete sanksjonsmiddel tilgjengeleg, som kan brukast til å straffe avvikande medlemmer.

Det er viktig at RFFO er opne for å inkludere nykommarar. Då unngår ein at dei set svært store unilaterale kvotar, for å tvinge partane til forhandlingsbordet. I makrellkonflikten førte nykommaren Island til at svakheita i regimet vart avslørt: Ein ønskte ikkje å legge til rette for nye partar, ei heller å reforhandle tidlegare avtalar. Makrellregimet har altså trekk som passar i den institusjonalistiske tilnærminga når samarbeidet fungerer. Då regimet faktisk møtte stor motstand, braut det saman raskt, og meir tradisjonell maktpolitikk såg ut til å dominere i perioden makrellkonflikten varte.

I den grad ein kan lære noko av denne undersøkinga, vil eg argumentere for at det målar eit bleikt bilete for framtidige klimakonfliktar. Utan ein rådande konsensus blant medlemmene vart sjølve grunnlaget for forvaltingsregimet trekt i tvil. Dette grunnlaget er ei forskings- og fornuftsbasert haldning til fiskeriforvalting, som skal sikre berekraft. Partane trekte i tvil kvarandres forsking og såg bort frå ekspertråd frå ICES. I skrivande stund ser det ut til at overfiske fortset, trass i kraftig reduksjon i ICES sine tilråda totalkvotar. Det denne artikkelen har bidrege med, er med andre ord å illustrere korleis svake internasjonale regime blir utfordra av mektige statlege aktørar. I møte med utfordringar som set på prøve etablerte fordelingsprinsipp, så vil eit svakt RFFO sannsynlegvis bli irrelevant i den faktiske fordelinga av ressursen. Det er mogleg å tenke seg at dette vil gjelde i andre tilfelle av liknande ressurskonfliktar. Vegen er med andre ord kort frå å vere eit fungerande, men svakt regime, til å bli eit irrelevant regime.

På det varmaste i konflikten, i 2014, vart det fiska 400000 tonn makrell meir enn ICES sin tilrådde kvote, som var på omtrent 1 million tonn (ICES, 2017, s. 10). 
ICES sin tilrådde kvote for 2019 er berre på 318403 tonn (ICES, 2018b, s. 1). Dette er ei relativt dramatisk endring, og det kan bety mange tapte kroner for partane.

Overfiske har konsekvensar. Dersom ein ikkje endrar kurs snart, kan bestanden kollapse. Det er ingen tente med, og kystnasjonane må no vise at dei tek berekraft på alvor.

\section{Om forfatteren}

Olav Anders Totland har tidligare forska ved Fridtjof Nansens Institutt med ressursforvalting og fiskeriforhandlinger som fagfelt. Han har en mastergrad i statsvitenskap frå Universitetet i Oslo med spesialisering i i Arktis og fiskeriforvalting.

\section{Litteraturliste}

Agreed Record of Conclusions of Fisheries Consultations between the Faroe Islands, the European Community, and Norway on the Management of Mackerel in the North-East Atlantic for 2009. Henta 1.09.2017 frå https://d3b1dqw2kzexi.cloudfront.net/media/3604/mackerel_agreed_record_2009_signed.pdf

Agreed Record on A Fisheries Arrangement between the European Union, the Faroe Islands and Norway on the Management of Mackerel in the North-East Atlantic for 2014 to 2018. Tilsendt meg den 31.01.2018 gjennom innsynsordninga til Nærings- og fiskeridepartementet.

Agreed Record of Conclusions of Fisheries Consultations between the Faroe Islands, the European Community, and Norway on the Management of Mackerel in the North-East Atlantic for 2017. Henta 09.02.2018 frå https:/www.regjeringen.no/contentassets/1219badf1329427b9270f914a6900de6/makrellavtal e-2017-nfi-eu.pdf

Anderson, D. H. (1996). The straddling stocks agreement of 1995: An initial assessment. The International and Comparative Law Quarterly, 45(2), 463-475.

Ásgeirsdóttir, Á. (2008). Who gets what? Domestic influences on international negotiations allocating shared resources. Albany, NY: State University of New York Press.

Bergensavisen. (2014, 6. mai). Ingen makrellavtale.

Burkett, V. R., Suarez, A. G., Bindi, M., Conde, C., Mukerii, R., Prather, M. J., St. Clair, A. L. \& Yohe, G. W. (2014). Point of departure. I C.B. Field, V. R. Barros, D. J. Dokken, K. J. Mach, M. D. Mastrandrea, T. E. Bilir, M. Chatterjee, K. L. Ebi, Y. O. Estrada, R. C. Genova, B. Girma, E. S. Kissel, A. N. Levy, S. MacCracken, P. R. Mastrandrea \& L. L. White (Red.), Climate change 2014: Impacts, adaptation, and vulnerability. Part A: Global and sectoral aspects. Contribution of working group II to the fifth assessment report of the Intergovernmental Panel on Climate Change (s. 169-194). Cambridge: Cambridge University Press.

BarentsWatch. (2012, 14. september). Store verdier på vandring.

Cendrowicz, L. (2010, 27. august). The Mackerel wars: Europe's fish tiff with Iceland. Time.

Collier, D. (2011). Understanding process tracing. PS: Political Science E Politics, 44(4), 823-830.

Dagens Næringsliv. (2012, 3. september). Ny forhandling løste ikke makrellfloken.

Europakommisjonen. (2017). Fishing quotas. Henta 18.09.2017 frå https://ec.europa.eu/fisheries/cfp/fishing rules/tacs_en

Eurostat. (2017). Fishery statistics. Henta 10.05.2018 frå https://ec.europa.eu/eurostat/statisticsexplained/ index.php/Fishery_statistics

Fish Update. (2014). Iceland finds willing markets for its mackerel. Henta 10.05.2018 frå https://www. fishupdate.com/iceland-finds-willing-markets-for-its-mackerel-fishupdate-com/

Gänsbauer, A., Bechtold, U. \& Wilfing, H. (2016). SoFISHticated policy - social perspectives on the fish conflict in the Northeast Atlantic. Marine Policy, 66(1), 93-103.

Hallwood, P. (2016). International public law and the failure to efficiently manage ocean living resources. Marine Resource Economics, 31(2), 131-139.

Hamre, J. (1993). A model of estimating biological attachment of fish stocks to exclusive economic zones. Henta 28.09.2018 frå https://core.ac.uk/download/pdf/52044311.pdf

Hannan, D. (2014). The Faroes have won their fisheries dispute with the EU. Feeling a bit ashamed, Britain? The Dailiy Telegraph. Lesedato 04.05.2018. 


\section{Olav Anders Totland}

Hannesson, R. (2013). Sharing a migrating fish stock. Marine Resource Economics, 28(1), 1-17.

Hardin, G. (1968). The tradegy of the commons. Science, 162(3859), 1243-1248.

Hasenclever, A., Mayer, P. \& Rittberger, V. (2000). Integrating theories of international regimes. Review of International Political Economy, 26(1), 3-33.

Havrettskonvensjonen. (1982). De forente nasjoners havrettskonvensjon. Henta 15.08.2017 frå https://www. fn.no/Om-FN/Avtaler/Miljoe-og-klima/Havrettskonvensjonen

Hayashi, M. (1993). The management of transboundary fish stocks under the LOS convention. The International Fournal of Marine and Coastal Law, 8(2), 245-261.

Henriksen, T. \& Hoel, A. H. (2011). Determining allocation: From paper to practice in the distribution of fishing rights between countries. Ocean Development and International Law, 42(1-2), 66-93.

Hotvedt, B. D. (2010). The problem of sharing a common stock: An analysis of the Mackerel conflict in the North East Atlantic [masteroppgave]. Universitetet i Tromsø.

Hop, H. \& Gabrielsen, G. W. (2013). Makrellen har kommet - til Arktis. Norsk Polarinstitutt 02.10.2013.

IceNews. (2009, 2. desember). Iceland asked to help set mackerel quota.

ICES. (2014). Report of the benchmark workshop on pelagic stocks (WKPELA). Henta 05.09.2018 frå http:// www.ices.dk/sites/pub/Publication\%20Reports/Expert\%20Group\%20Report/acom/2014/WKPELA \%202014/WKPELA\%20Report\%202014.pdf

ICES. (2017). ICES Advice on fishing opportunities, catch, and effort. Northeast Atlantic. Henta 30.08.2017 frå http://www.ices.dk/sites/pub/Publication\%20Reports/Advice/2016/2016/macnea.pdf

ICES. (2018a). Report on the working group on mackerel and horse mackerel egg surveys (WGMEGS). Henta 05.09.2018 frå http://ices.dk/sites/pub/Publication\%20Reports/Expert\%20Group\%20Report/EOSG/ 2018/W GMEGS/WGMEGS\%20report\%202018.pdf

ICES. (2018b). ICES Advice on fishing opportunities, catch, and effort. Ecoregions in the Northeast Atlantic and Arctic Ocean. Henta 01.10.2018 frå http://ices.dk/sites/pub/Publication\%20Reports/ Advice/2018/2018/mac.27.nea.pdf.

IPPC. (u.å). The regional impacts of climate change. Henta 03.10.2018 frå http://www.ipcc.ch/ipccreports/ sres/regional/index.php?idp $=43$

IPPC. (2018). Global warming of $1.5^{\circ} \mathrm{C}$. Henta frå http://report.ipcc.ch/sr15/pdf/sr15_spm_final.pdf

Jackson, R. \& Sørensen, G. (2006). Introduction to international relations theories and approaches. Oxford: Oxford University Press.

Jensen, Ø. (2008). Kontinentalsokkelens avgrensning utenfor 200 nautiske mil: Norske og russiske perspektiver i de nordlige havområder. Lov og Rett, 66(4), 563-705.

Krasner, S. (1982). Structural causes and regime consequences: Regimes as intervening variables. International Organization, 36(2), 185-205.

Lawler, J. J., Tear H, T., Pyke, C., Shaw, R, M., Gonzalez, P., Kareiva, P., Hansen, L., Hannah, L., Klausmeyer, K., Aldonus, A., Bienz, C. \& Pearsall, S. (2010). Resource management in a changing and uncertain climate. Frontiers in Ecology and the Environment, 8(1), 35-43.

Malnes, R. (2011). Det globale anarkiet. I J. Hovi \& R. Malnes (Red.), Anarki, makt og normer. Innføring $i$ internasjonal politikk (s. 15-28). Oslo: Abstrakt forlag AS.

Meld. St. 26 (2010-2011). Fiskeriavtalane Noreg har inngått med andre land for 2011 og fisket etter avtalane $i$ 2009 og 2010.

Ministry of Fisheries and Natural Resources. (2018). Faroe Islands fisheries \& aquaculture. Responsible management for a sustainable future. Henta 04.05.2018 frå http://d3qmf0vbw06tnc.cloudfront.net/ media/1715/fo_fisheries_and_aquaculture.pdf

NEAFC. (1980). Convention on future multilateral cooperation in North-East Atlantic fisheries. Henta 18.09.2017 frå https:/www.neafc.org/system/files/Text-of-NEAFC-Convention-04.pdf

NEAFC. (2008a). Report of the 27th annual meeting of the North-East Atlantic Fisheries Commission 10-14 November 2008, volume II- Annexes. Henta frå https://www.neafc.org/system/files/27neafc_annual_2008_ vol2_annexes.pdf

NEAFC. (2008b). Report of the 27th annual meeting of the North-East Atlantic Fisheries Commission 10-14 November 2008, volume I- Report. Henta frå https://www.neafc.org/system/files/27neafc_annual_2008_ vol1_main-report.pdf

Nielsen, M., Andersen, P., Ravensbeck, L., Laugesen, F. M., Andersen, J. L., Kristofersson, D. M., Reithe, S., Nilssen, J. \& Ellefsen, H. (2010). Samfundsøkonomisk afkast af pelagiske fiskerier $i$ nordøstatlanten. Henta 10.05.2018 frå http://research.ku.dk/search/?pure=en\%2Fpublications\%2Fsamfundsoekonomisk-afkastafpelagiske-fiskerier-i-nordoestatlanten(6a5412a0-bf39-11df-825b000ea68e967b)\%2Fexport.html 


\section{Makrellkonflikten og strategisk klimafornekting}

NIFES. (2015). Makrell. Henta 30.08.2017 frå https://www.nifes.no/forskningstema/tryggsjomat/overvakningav-sjomat/makrell-2/

Nofima. (2014). Makrellkonfliktens konsekvenser. Henta 20.02.2018 frå https://nofima.no/pub/1157010/

Nordic Marine Think Tank. (2015). Allocation of fishing rights in the NEA. Henta 16.09.2018 frå http://nmtt. org/images/documents/topics/allocation/TN2015546\%20web.pdf.

Ny Tid. (2010). Ingen glade laks. Henta 23.05.2018 frå https://web-retriever-infocom.ezproxy.library.bi.no/ services/archive/displayPDF?documentId=055099201009103qhgh B4CIsSD1cdSca1RBu3B100201010o1 $\mathrm{k} \&$ serviceId=2

Oberthür, S. \& Stokke, O.S. (2011). Managing institutional complexity. Regime interplay and global environmental change. Boston, MA: The MIT Press.

One Shared Ocean. (2017). LMEs. Henta 21.09.2017 frå http://onesharedocean.org/lmes

Opne hav-avtala. Avtale om gjennomføring av bestemmelsene $i$ De forente nasjoners havrettskonvensjon om bevaring og forvaltning av vandrende fiskebestander og langtmigrerende fiskebestander. Henta 15.08 .2017 frå https:// lovdata.no/dokument/TRAKTAT/traktat/1995-08-04-1

Óskarsson, G. J., Sveinbjörnsson, S., Guðmundsdóttir, Á., \& Sigurðsson, T. (2012). Ecological impacts of recent extension of feeding migration of NE-Atlantic mackerel into the ecosystem around Iceland. Henta 04.09.2017 frå http://www.ices.dk/sites/pub/CM\%20Doccuments/CM-2012/M/M0312.pdf

Ostrom, E. (1992). The rudiments of a theory of the origins, survival, and performance of common-property institutions. I D. W. Bromley \& D. Feeny (Red.), Making commons work. Theory, practice and policy (s. 293-318). San Francisco: ICS Press.

Polasky, S., Carpenter, S. R., Folke, C. \& Keeler, B. (2011). Decision-making under great uncertainty: environmental management in an era of global change. Trends in Ecology E Evolution, 26(8), s. 398-404.

Putnam, R. D. (1988). Diplomacy and domestic politics: The logic of two-level games. International Organization, 42(3), s. 427-460.

Sarewtiz, D. (2004). How science makes environmental controversies worse. Environmental Science and Policy, (7), 385-403.

Selmer, A. A. (2016, 14 november). Her utnyttes 95 prosent av fisken. PUTSF.

SSB. (2017). Fiskeri, 2017, årleg, førebelse tal. Henta 02.02.2018 frå https://www.ssb.no/jord-skogjakt-ogfiskeri/statistikker/fiskeri/aar-endelige

Štulajter, M. (2017). Problem of enforcement of an international law - analysis of law enforcement mechanisms of the United Nations and the World Trade Organization. Fournal of Modern Science, 33(2), s. 325-335.

Spijkers, J. \& Boonstra, W. J. (2017). Environmental change and social conflict:The northeast Atlantic mackerel dispute. Regional Environmental Change, 17(6), 1835-1851.

Sunnmørsposten. (2012, 7. november). Forsvarte «makrellpiratar». Sunnmørsposten.

Sherman, K., Belkin, I., Friedland, K. D. \& O'Reilly, J. (2013). Changing states of North Atlantic large marine ecosystems. Environment, Development and Sustainability, 7(1), 46-58.

Stokke, O. S. (2011). Internasjonale regimer. I J. Hovi \& R. Malnes (Red.), Anarki, makt og normer. Innføring $i$ internasjonal politikk (s. 271-300). Oslo: Abstrakt Forlag.

Underdal, A. (2004). Methodological challenges in the study of regime effectiveness. I A. Underdal \& O. Young (Red). Regime consequences. Methodological challenges and research strategies (s. 27-48). Dordrecht: Kluwer Academic Publishers.

Underdal, A. (2011). Internasjonale forhandlinger. I J. Hovi \& R. Malnes (Red.), Anarki, makt og normer. Innføring i internasjonal politikk (s. 246-270). Oslo: Abstrakt Forlag.

Underdal, A. (2013). Meeting common environmental challenges: The co-evolution of policies and practices. International Environmental Agreements, 13(1), s. 15-30.

Vartdal, B. (2012, 25. april). Truer Island og Færøyene med makrellkrig. Sunnmørsposten.

World Fishing. (2014). Europe's mackerel war wanes. Henta 14.09.2017 frå http://www.worldfishing.net/ news 101/Comment/analysis/europes-mackerel-war-wanes

Wettestad, J. (1999). Designing effective environmental regimes: The key conditions. Cheltenham: Edward Elgar Publishing.

Wendt, A. (1992). Anarchy is what states make of it: The social construction of power politics. International Organization, 46(2), 391-425.

Young, O. (1998). Institutional uncertainties in international fisheries management. Fisheries Research, 38(1), 211-224.

Ørebech, P. (2013). The "lost mackerel" of the North East Atlantic - the flawed system of trilateral and bilateral decision-making. The International fournal of Marine and Coastal Law, 28(2), 343-373. 


\section{Abstract in English \\ The Mackerel War: How Climate Change Impacts \\ Fishery Negotiations and Regimes}

How well are international resource management regimes equipped to handle climate change? Are such regimes able to adapt to and include new players, or do the stakeholders prefer status quo? This article will explore this phenomenon by using the case of the Mackerel War in the Northeast-Atlantic during 2008-2014. The mackerel stock in the Northeast-Atlantic changed its migratory pattern, which triggered the Faroe Islands to renegotiate its deal with Norway and the EU. Simultaneously, Iceland became a new major player in the mackerel fisheries. The mackerel regime consisting of Norway, EU and the Faroe Islands experienced a temporary breakdown during the conflict. This led to substantial overfishing. Due to differing interpretations of international conventions as well as the addition of a newcomer, the regime was not able to adapt well to the changing situation. Research on climate change was doubted by the states and was used strategically to legitimize resource claims. The fisheries regime needs stricter and more consistent rules regarding the inclusion of newcomers in fisheries, as well as how to handle dramatic changes in migratory patterns.

Keywords: fisheries - resource management $\cdot$ Arctic $\cdot$ climate change 